\title{
Germany and Greece: A Mapping of their Great Divide and its EU Implications
}

\author{
George C. Bitros ${ }^{1}$
}

\begin{abstract}
:
The economic constitutions of Germany and Greece have resulted in the post-war period in two economies that are based on two vastly different philosophies.

Germany has built a highly competitive, outward looking economy based essentially on the principles of the so-called "Social Market Economy", whereas Greece has set up a "statemanaged economy" by drawing on the principles of central planning and administrative controls.
\end{abstract}

This divide is equally stark, if assessed on the basis of the performance of the two economies. For, as it is known by now, Germany has become once again the powerhouse of Europe while Greece has gone bankrupt.

As to the implications of this great divide for the future of the EU, its identification and mapping helps understand why convergence criteria on the basis of economic performance and living standards should be abandoned in favour of criteria based on the widening and deepening of the four European freedoms.

A multispeed Euroland enmeshed in these freedoms is going to be more democratic, more cohesive and a much happier union for the European citizens to call homeland.

Keywords: Social market economy, central planning, economic performance, structural differences, four European freedoms.

JEL Classification: E02, F02, P51, H1, L5.

\footnotetext{
${ }^{1}$ Emeritus Professor of Political Economy, Athens University of Economics and Business, email: bitros@aueb.gr
} 


\section{Introduction ${ }^{2}$}

The visionaries who embarked in the 1950s on the monumental project of European unification aimed initially at economic integration. They envisioned that efforts towards this objective would evolve in three stages. In the first stage, the memberstates would join in a customs union, eliminating all trade and non-trade barriers among them. Then, upon sufficient progress, a second stage would follow in which efforts would turn to forming an economic union. At this stage market institutions and functions would be merged across all member-states so that a common production, distribution and exchange economy would emerge based on four principles, i.e., uninhibited mobility of goods, services, capital, and workers. Finally, in the third stage, the member-states would abolish their national currencies and join in a monetary union. Throughout these stages all arrangements would be negotiated well in advance and every country that joined would be committed to adjust its economic policies accordingly. For them as founding fathers the expectation was that at the end of this long process, and in the light of the results that would have been achieved, the economic bonds among member-states would have grown strong enough to withstand the difficulties that any attempt at political integration would entail.

Following the signing of the Treaty of Rome in 1957 and over the next several decades the prospects of European unification kept improving. Many European countries sought and joined initially the European Economic Community (EEC), later on became full members of the European Union (EU), and in the 1990s entered into the European Monetary Union (EMU) by adopting the Euro as their single national currency. Every time major hurdles arose in the negotiations over various thorny issues, member-states showed exemplary good will in working out compromises; and whenever decisions involved transferring of powers from the periphery to the centre, a strong spirit of unification enabled member-states to surpass whatever nationalistic and idiosyncratic objections they might have. In short, the progress was intermittent and reflected not only the benefits of member-states from the synergies of economic integration but also other long term strategic advantages associated with the building of a major union-state with global presence and ambitions along with the other super-powers in the world.

However, more recently, and particularly since the 2008 financial crisis in the U.S, which spread quickly to several member-states and revealed many fragile arrange-

${ }^{2}$ I am indebted to several friends and colleagues who read this paper and offered me their advice. From among them I wish to single out George Tridimas and Spyridon Paraskevopoulos for their valuable comments and suggestions. Also, Constantinos Christidis read the text and drew my attention to certain linguistic obscurities. To them and to the others who helped me improve the paper in one way or another, I express my thanks and sincere appreciation. Needless to say I remain solely responsible for any remaining errors of fact or interpretation. 
ments in the functional and institutional structure of EU, the prospects of European unification turned sour and pessimism started to mount. As a result, experts and common people who had been previously excited with the possibility of a United States of Europe in the distant future now find themselves at a loss and put the blame on various causes. Some, for example, hold responsible the bureaucracy in Brussels for the difficulties they are creating in the everyday lives of European citizens through their bias towards overregulation. ${ }^{3}$ Some others point to the failure of central EU authorities to deal promptly and effectively with events like the debt crisis in the countries of the Mediterranean South and the influx of illegal immigrants and refugees from poor and war torn countries of Asia and Africa. Still some others blame the loss of representativeness on the part of the European Commission (EC), which in their view has come under the control and influence of Germany. To be sure, depending on one's personal dispositions and information, one may find more or less merits in these criticisms. But integration was accompanied always by arrangements that required compromises, at times painful from a national point of view, and yet staying the course in the process of European unification was never in doubt, at least not until the decision last year by the United Kingdom to leave and the emergence of populist political parties, which seek election on closed economy and leave from EU platforms.

At this juncture the results from last year's elections in France are encouraging. Hopefully, no other major EU member-state will leave and the centrifugal effects from the departure of the United Kingdom may fade away soon. Yet these difficulties should not deter the study of the problems that hinder EU from making progress in the front of unification. The present paper is motivated exactly by this spirit. In particular, it focuses on two member-states, i.e. Germany and Greece, in pursue of three objectives: To identify the fundamental differences in their institutional and organizational structure; to assess the extent to which these differences have contributed to the spectacular differences in their performance, and lastly, to map the implications of the findings for the European project. For, if the same differences hold more generally among advancing and lagging member-states, the European project may come to a standstill, if not completely abandoned due to growing divisions and disparities.

From the contrast of their present circumstances it emerges that between Germany and Greece there is a divide which is as great as that which differentiates the "liberal" from the "statist" ideas and approaches to democracy and market economy. In the post-war period, Germany adopted the former and reached new and sustainable highs in world power and material well-being, whereas Greece adopted the latter and after

\footnotetext{
${ }^{3}$ This charge, frequently stressed in the British press, is reminiscent of the sharp criticisms Thatcher, late prime minister of the United Kingdom, systematically addressed in the 1980s at the central administrative authorities in Brussels. It has received support by authors like Siedentop (2001). However, forceful and convincing counterarguments abound. For example, see Moravscik (2001).
} 
two decades (1954-1974) of remarkable state-driven economic growth and subsequently four decades of decline (1975-2009), in 2010 it went bankrupt. ${ }^{4}$ These results support the superiority of the liberal over the statist model and, in conjunction with the evidence that the institutional arrangements in France and the other countries of the European south are more or less statist, they imply that unification is threatened more by the differences over issues of democracy and economy rather than differences in per capita income or other welfare and cultural indices. ${ }^{5}$ Hence, on this ground, it is concluded that the ultimate test is whether these member-states will be willing or not in the coming years to streamline their political and economic institutions along lines, at least as liberal ${ }^{6}$ as those prevailing currently in Germany. If not, which is more likely, the European project in its present form will be abandoned and the aspirations for unification will shrink to include only those Northern member-states with rather liberal orders of institutions and organization.

The presentation in Section 2 immediately below starts with a brief flashback into the ideas and approaches to issues of democracy and economy that prevailed in Germany and Greece in the post-war period. Since it is these that shaped their institutional arrangements, this flashback should facilitate interested readers in understanding the roots of the enormous differences in the directions Germany and Greece chose to follow regarding their political and economic organization. In Sections 3 and 4 the focus turns on the principles that underlie and the structure that characterizes the German and the Greek model of market economy. Of these two models, the latter is unknown to foreign audiences. For this reason the emphasis of the presentation is on the ideas and principles on which it stands as well as the structure of its building blocks. But in general the effort in these sections is to hold them short in order to keep the length of the paper within reasonable bounds. Lastly, Section 5 identifies and assesses the differences between the two models; and Section 6 closes with a summary of the findings and the conclusions.

${ }^{4}$ Tables 1 and 2 in the Appendix provide two sets of indicators that highlight the vast differences among Greece and Germany in terms of living standards and working conditions, on the one hand, and the quality of institutions and governance, on the other. The point this paper aspires to make is that these differences have grown wider over recent decades because of the differences in the social and economic organization of the two countries.

${ }^{5}$ For an enlightened assessment of fundamental differences emanating from these sources that result in the weakening of the bonds of solidarity among European peoples, see also Habermas (2018).

${ }^{6}$ In 2008, i.e. the year before the economic crisis erupted in Greece, public spending in Germany and Greece was $43.6 \%$ and $50.8 \%$ of GDP, respectively. Hence, on this basis, Germany was nearly as statist as Greece. But on numerous other criteria, Germany has been generally a much-much "freer" country. Hence, the terms "liberal" and "statist" are used somewhat loosely to signify the wide differences between the two countries on the basis of an overall index of freedom from state intervention. 


\section{On the evolution of ideas and policies in Germany and Greece}

In the aftermath of the 1929 crisis, certain economists and politicians in Germany and Greece were thinking hard about the reforms that ought to be adopted in order to bring the political and economic organization in their countries into alignment with the thorny problems they faced. Before WWII started in 1940 their ideas and proposals received scant attention. But they came to a heading during the war and shortly after. In retrospect, it turns out that over the period from about 1935 to 1950 a battle of ideas took place, the outcome of which determined in each country the shape of institutions and the direction of social and economic policies until about 1970. Around that time the intellectual and political environment in both countries changed in favour of more interventionist policies, thus leading to the differences in their present institutional and organizational structures. The focus below is on the protagonists and the ideas that were debated in the two periods and what the outcomes were. By undertaking this brief flashback, the objective is to place the shifts in each country in the context of the historical circumstances in which they took place so as to enable the readers to relate the ideas and policies to the results.

\subsection{The Protagonists and their Influence in Germany ${ }^{7}$}

In the aftermath of World War I the structure of the German economy continued to become more and more concentrated with the formation across all sectors of monopolies, cartels and other types of business agglomerations of economic power. According to Barry $(2013,2)$, concentration had advanced to such an extent that, when in the early 1930s Hitler laid down his plans for building the German war machine, he did not need to nationalize anything. ${ }^{8}$ Under these circumstances it is not surprising that freedom loving academics would take the lead in developing and disseminating ideas and proposals for the next day, i.e. when freedom would return. Thus, in the mid-1930s emerged a group of distinguished thinkers, some based in the University of Freiburg and led by Walter Eucken, Franz Böhm and Fritz Meyer (the Freiburg group), and some based abroad and led by Wilhelm Röpke, Alfred MüllerArmack and Alexander Rüstow (the group of so-called "exiles"), who presented a

\footnotetext{
${ }^{7}$ For a brief, lucid and highly informative account of the intellectual and business climate that prevailed in Germany in the decades leading to the 1948 break with the past in policy thinking, see Hasse (2017).

${ }^{8}$ Additionally it should be noted that the advanced concentration in the German economy during the early decades of the $20^{\text {th }}$ century was encouraged by the prevailing intellectual and social climate. For example, in the 1920s the so-called "Socialists of the chair" and the younger adherents of the Historical School of Economics argued in favor of deep intervention by the state into the economy to confront the problems of unemployment, inflation and deficits in the balance of payments. On the other hand, the existence of very strong socialist parties suggests that large majorities of Germans sought state paternalism. As a result, it is said, jointly these conditions opened the door to the defeat of the Weimar Republic and the rise of Hitler to dictatorship.
} 
new strain of liberalism known as "Ordo-liberalism", "liberalism of the rules", or "Social Market Economy".

They founded it on three pillars. First, by rejecting the fundamental precept of "classical liberalism" (according to which, if the size of the state is small, thus leaving the social and economic processes mainly to themselves), in a democracy the selfcoordinating forces in society and economy bring about results that cannot be improved without reducing individual freedoms and efficiency in the use of productive resources. Second, by asserting that before these optimal results might take effect, uninhibited freedom beyond the laws for protecting natural rights would destroy freedom itself. For in that event, they claimed, unconstrained contracting in the framework of voluntary exchanges would lead to monopolies, cartels and other concentrations of economic power; without careful design, governments would be captured by organized interest groups; and, in general, a small government restrained from intervening to streamline market forces would be unable to maintain order, justice, predictability and ultimate the market system itself; And thirdly, by laying down the principles for establishing an Ordoliberal regime in real life.

Their key idea in this regard was that, aside from the political constitution that aims to restrain the powers of the state to protect civil liberties, there would be another constitution which would prescribe rules under which the state would be restrained to intervene in the economy to protect economic freedoms. Hence, since how liberal the emerging regime would be depends on the provisions in this socalled "economic constitution", the debate turned on the breadth and depth of state intervention. This is exactly where the two groups split. According to Vanberg (2004, 2), the Freiburg group maintained that: (a) the market as a nondiscriminating, privilege-free system of competition, is in and by itself an ethical system, and (b) it can and should be combined with a system of minimal income guarantee for those who are temporarily or permanently unable to earn a living through the market. On the contrary, the group of exiles proposed that: (a) the market is a "technical instrument" that can be used by society to produce wealth, yet it does not make itself for a "good" society, and hence (b) it should be supplemented by "social provisions" that are supposed to make the market economy beyond its economic efficiency - ethically appealing. From this account of their differences it follows that Eucken and his followers argued in favour of a relatively small state with limited powers to intervene in the economy, whereas MüllerArmack and those who followed him supported a relatively larger state with wider powers of intervention.

Immersed in these ideas, particularly those of the Freiburg group, was Ludwig Erhard who was destined after the war to play an instrumental role in their translation to actual policies for speeding up reconstruction in the then West-Germany. ${ }^{9}$ Thus,

${ }^{9}$ According to Baum (1990, 178) Erhard precluded adopting the Scandinavian model. He considered it too statist and conducive to undermining individual responsibility, which he 
soon after he was elected director of economics by the Bizonal Economic Council in 1948 and Minister of Finance in the government of Conrad Adenauer in 1949, he embarked on a far-reaching liberalization program, scrapping all price controls, introducing the Deutschmark as new currency, establishing the Bundesbank as an independent monetary authority, etc., and leaving the markets to operate freely. We know that he did so by conviction not only because he went against the plethora of German supporters of hard core statist and Keynesian policies, ${ }^{10}$ but also because, according to Barry $(1993,9)$, he ignored all warnings from the American administration of allied forces who, drawing on the advice of such eminent economists as John Galbraith, were determined that West Germany should not have a liberal market economy. What all these adversaries predicted was that Erhard's Ordoliberal policies would lead to high inflation, deceleration of investment and high unemployment. Yet all their predictions proved wrong and by 1960 the West German economy had performed beyond any expectations. ${ }^{11}$

After 1960 the grip of Ordoliberal politicians and academics on the developments started gradually to wane. Due mainly to the newly accumulated wealth and the increasing distance from the halcyon 1945-1948 days, the importance of limited government intervention that had been impressed in the minds of Germans diminished, whereas Keynesian and Central Planning inspired academics and politicians stirred the demand for more and more government interventions in pursue of such objectives as controlling the business cycle, stimulating growth, stabilizing prices, maintaining full employment, building a more equitable society, etc. ${ }^{12}$ According to Rittershausen $(2007,43)$, by 1966 popular support for Keynesian policies was such that Ludwig Erhard who was Chancellor at the time:

"... was forced to consider some sort of Konjuncturpolitik and the general coordination of economic policy. Even after his Social Market

thought was absolutely necessary for the speedy recovery and the future of Germany in the long run.

10 Rittershausen (2007, 20-38) provides a very detailed account of the battle among various groups from politics, academia and labor unions, as well as the proposals they submitted in the critical period 1945-1948.

${ }^{11}$ There is a voluminous body of literature that attributes much of the so-called "German miracle" of 1952-1960 to reasons other than the policies adopted under the model of Social Market Economy. For an extended review of this literature, see for example Van Hook (2004). However, given the tectonic shifts that took place in policy thinking in 1948 under Ludwig Erhard, it would be farfetched to surmise that this decisive departure from the socialist prewar regime did not contribute significantly to the rates and sustainability of Germany's postwar progress.

${ }^{12}$ The evidence assembled by Rittershausen (2007, 31-38) points convincingly towards the assessment that the two economists who spearheaded the intellectual shift in academia and politics towards this direction were Karl Schiller and Erich Preiser. However, note that according to Hasse (2017, 100), both of them as scholars and policy designers and practitioners are classified as "creators and performers of the Social Market Economy." 
Economy aura was irreparably breached by recession, Erhard's proposals remained half-hearted attempts to stave off an increasingly Keynesian-leaning electorate."

Finally, the triumph of Keynesianism over Ordoliberalism was recognized officially in May 1967 with the passage of the Law for the Promotion of Economic Stability and Growth, which gave federal policymakers wide discretionary authority not just to conduct demand management policies but to use fiscal and other policy means of intervene deep into the economy.

In the years since then many authors have assessed the results of the policies and the institutional arrangements that were put in place under the above law and its numerous amendments in the same spirit. For example, Giersch et al. (1994) found that the interventionist ideas and policies during the period 1960-1989 not only failed to realize most of the objectives for which they had been adopted, but also that they gave rise to major supply-side problems and to a significant expansion in the government sector. However, nothing helped more in stemming, if not reversing, the tide of interventionism in Germany than two powerful developments that took hold since the early 1980s. The first of them is the victory of liberal ideas and policies over Keynesianism, particularly in the U.K and the U.S. Slowly but surely the election of Margaret Thatcher in the U.K. in 1979 and Ronald Reagan in the U.S. in 1981, both of whom won on platforms based on the teachings and writings of such great philosophers and economists like Friedrich A. Hayek ${ }^{13}$ and Milton Friedman, gave impetus to "pro-market", "pro-deregulation" and "pro-roll-back-the-state" policies around the world and changed the balance of dominance in academia in favour of the called "neo-liberal" thinking. Germany did not remain immune to these shifts and the fact that in the present German Council of Economic Experts only one out of five members is seen as Keynesian attests to the conclusion that interventionism has been in long term retreat.

The second development has to do with the act for the Single European Market in 1986. This was the first major revision of the 1957 Treaty of Rome and it set the European Community on a path to establishing a single market based on four freedoms, i.e. free and uninhibited movement of goods, capital, services, and people. But these freedoms are embedded as an integral part in the ideas and policies Ordoliberals have been adhering all along. Did Ordoliberalism re-enter Germany from the back-door of EU? The answer is in the affirmative and it is amply highlighted by the interesting details reported by Hasse (2017). From them we learn that the head of the German delegation in the negotiations for the Treaty of Rome was Alfred Müller-Armack, who served at the time under Ludwig Erhard as Deputy Minister in the Ministry of Economics and in charge for all European Economic Affairs.

${ }^{13}$ Hayek has been among the intellectual progenitors of the Social Market Economy. To get a glimpse into his relationship with other members in the Freiburg group and the group of the exiles, see Hasse et al. (2008, 40-42). 
Accordingly, given his strong liberal convictions as well as those that prevailed among the members of the German delegation, it is hardly surprising that the Treaty of Rome bears the imprint of Ordoliberals and that its revision in 1986 expanded and deepened the provisions for the realization of the four freedoms across all EU member-states. ${ }^{14}$

To conclude, since the 1980s the dominant coalition of Keynesian and other interventionists in Germany came under attack from two main directions. That is, first, from the international shift towards "neo-liberal" ideas and policies, and, second, from the Ordoliberal requirements as mandated from the treaty for the Single European Market. As a result, even though in the meantime Germany transformed into an advanced "Welfare state" with all the rigidities and inefficiencies associated with it, ${ }^{15}$ to a great extent it has grown into a liberal democracy and economy.

\subsection{The Protagonists and their Influence in Greece}

As happened in Germany in the early decades of the $20^{\text {th }}$ century, the ideas of classical economists regarding the role of the state in the economy retreated also in Greece. But unlike Germany, where Ordoliberalism started to take roots in the interwar years, during the same period in Greece the intellectual and policy climate was predominantly in favour of economic planning and large-scale state interventions in the economy. As a result in the late 1940s this divergence led to an Ordoliberal economy in Germany versus a state-managed economy in Greece. Since then, after several decades of decline, Ordoliberalism in Germany has been enjoying a revival by riding on the back of neoliberal ideas and the four freedoms of the Single European Market, whereas the model of state-managed economy in Greece has veered all the time towards state socialism, despite all expectations that within EU this trend would be reversed. Having outlined above how shifts in ideas influenced these trends in Germany, the objective here is to do the same in the case of Greece.

According to Hatzivassiliou (2010, 3-5), the academics, academics-turn-politicians and politicians who contributed with their ideas and initiatives to the regime that was established in Greece in the late 1940s may be classified largely into three groups. The first was led by Panayiotis Kanellopoulos, the second by George Papandreou, and the third by the duo of Xenophon Zolotas and Constantinos Tsatsos. ${ }^{16}$ All three groups

${ }^{14}$ That this is the case can be ascertained also by reference to the ample evidence that the policies of the European Commission frequently conflict with statist and interventionist policies pursued by German governments. For an interesting case to this effect, see Smith (2001).

15 In support of this view, see also footnote 2.

16 Certain literature suggests that the ideas to which leaders are exposed in their university studies determine to some extent the nature of policies they sponsor later when in public office. If so, it may be of interest to note that Kanellopoulos and Tsatsos graduated from the University of Heidelberg, Zolotas from the University of Leipzig, and Papandreou from the Humboldt University of Berlin. The ideas that held sway in these and other German universities at the time were those of the historical school and the school of state socialism. 
supported highly interventionist reforms. But differences of emphasis and degree in the particular policies, as well as in the approaches for their implementation, prevented them from finding common ground. So when at some point or another they evolved into separate political parties, they were very small to gain any traction with the electorate. To highlight the gist of what they proposed and given that the third group comprised people who influenced developments well into the $1980 \mathrm{~s},{ }^{17}$ in Bitros and Karayiannis (2011) we focused mainly on the views that Zolotas and Tsatsos expounded. Not surprisingly we found evidence suggesting beyond reasonable doubt that what they proposed was the establishment of an advanced regime of state socialism along the lines that had been propagated by contemporary socialist authors.

Had communists won in the civil war, most likely some version of the economic and social organization envisaged by Zolotas in 1943 and of the constitution that Tsatsos had drafted shortly thereafter would have been imposed and Greece would have turned into a communist state. ${ }^{18}$ From Tomai (2011) and others we know that this development did not materialized because, when the WWII ended and the allies decided that it was time to change the course of events in Greece, the balance of the debate between the above mentioned reformists and the officials of the American Mission for Aid to Greece (AMAG) regarding the country's institutional and organizational setup shifted in favour of less socialist alternatives.

This assessment differs materially from that arrived by other distinguished scholars. For example, summarizing his findings, Hatzivassiliou $(2010,1)$ concludes that:
"Since the mid-1930s, members of an indigenous reformist movement had advocated principles of political, social, and economic reform similar to those promoted by Washington through the European Recovery Program (ERP) beginning in 1947-1948. These reformist plans had been buried under the weight of the country's polarization and the subsequent civil strife. The Truman Doctrine and Marshall Plan were instrumental in reviv- ing the dynamism of these domestic reformist forces which would shape the country's development in the ensuing decades.

The difference lies in that the reforms the Americans promoted in Greece under the European Recovery Program (ERP) were fundamentally of a Keynesian bent and

Hence, given that the political platforms of all three groups called for a systematic intervention of the state in the economy as a means of rationalizing the economic, social, and political life of the country, it is rather unlikely that the German intellectual connection of these Greek leaders did not play a pivotal role in the shaping of the ideas and policies that were expounded by their groups.

${ }^{17}$ Key members were academic Angelos Angelopoulos, former ambassador Ioannis Politis, the young politicians Constantinos Karamanlis, Petros Garoufalias, Georgios Mavros, and Petros Kokkalis.

${ }^{18}$ The references here are to Zolotas (1943/2009) and to the draft of the constitution from that period that was found in Tsatsos's archives upon his death in 1987. 
involved neither extensive nationalizations across all sectors of the economy, nor the numerous other forms of interventions that the Greek reformists supported. This is particularly true with respect to those from the group that Zolotas and Tsatsos headed who became influential and leaned heavily in favour of a State-managed economy and society. ${ }^{19}$ Simply put, in view of the priorities the Americans pursued and the difficulties the country faced, these reformists compromised and shelved their ideas and plans for later. If there is any doubt about the highly interventionist policies they adopted from the high government positions they occupied in the 1950s, the following criticisms addressed by Andreas Papandreou (1962) regarding the crooked structure of the Greek economy that they established suffice to entertain it:

"There is a pressing need to streamlining the presently cumbersome "system" of government regulation of economic activity. In some sense there is "too much" government on the Greek economic scene, while there is too little research and too little planning, and the organizational apparatus for the execution of various plans is practically absent. The mosaic of fiscal credit and market regulations which are subject to abrupt changes without notice can hardly be expected to encourage private investment activity of the right kind" (p. 103).

"Where the market mechanism, the competitive process is allowed to perform the resource-allocation task, it ought to be allowed to work. The rewards for success should be high - but so should be the penalties for failure. The barriers to entry - which in Greece reach unusual heights ought to be lower if not removed. "Saturated" lines of endeavor and "closed" professions ought to be exposed to the rigors of the competitive process" (p. 104).

"...It is essential to come to understand that an efficient export sector cannot be grafted upon an inefficient economy. Greece's low capacity to export is a symptom of structural weakness, of resource misallocation, of missing links in the distribution chain - and should be handled as such. Special measures, such as preferential credit and fiscal treatment for export-oriented firms, while of doubtful effectiveness in the short-run, are often distinctly harmful in the long-run" (p. 105).

Such was his dismay that when he came to think about the future of the country in the European Economic Community (EEC) he wrote: ${ }^{20}$

19 Over the period 1950-1990 Zolotas served repeatedly as governor of the central bank, capping his career as prime minister in 1989; throughout his public life Tsatsos served as parliamentarian, minister and president of the republic; Karamanlis became twice prime minister and president of the republic.

${ }^{20}$ Greece became associate member of EEC in June 1961 and full member effectively in January 1, 1981. 
"Greece has recently concluded an Association Agreement with the European Common Market with the prospect of full membership some 22 years hence. It is fair to say that, given the terms of the association, Greece has a small margin of time in which to achieve the structural transformations needed for survival in the European Common Market" (p. 25).

However, when he became head of the Pan-Hellenic Socialist Movement in the 1970s and prime minister of Greece in the 1980s and 1990s, he spared no effort to push the structure of the Greek economy even further away from that needed to survive in the EEC, thus committing an awesome inconsistency which is not unrelated to the hellish circumstances that hit Greece more recently. ${ }^{21}$

In the mid-1970s the model of state-managed economy that Zolotas-TsatsosKaramanlis and their associates set up in the 1950s shifted decisively towards statesocialism. This development assumed the form of a new economic constitution which was embedded in the 1975 constitution as their brainchild. ${ }^{22}$ Since then its provisions, revised and supplemented consistently towards more central control, moved the structure of the Greek economy opposite to the direction that was mandated both by the advancing globalization of world trade and the 1957 Treaty of Rome, the 1986 Single European Market and the 1999 Growth and Stability Pact.

Added protagonists in this trend were Andreas Papandreou, ${ }^{23}$ Constantinos Simitis, Constantinos Karamanlis Jr., Miltiades Evert, etc. and numerous other academics and politicians with Keynesian and hard core socialist persuasions. If it is somewhat ironic that all these gentlemen at one time or another expressed their concern about the need for structural reforms and the possibility that Greece might not survive otherwise in the competitive environment of EEC, never mind. They were politicians and many of them are still around managing to no avail Greece's state of bankruptcy.

Drawing on the above as well as on Bitros (2013) and Thalassinos, Stamatopoulos (2015), it is safe to conclude that responsible for the present awful circumstances in Greece are the statist policies that were adopted in the post war period. Germany has an Ordoliberal economy, whereas Greece has a state-managed economy in which the four freedoms of the single European market remain still in abeyance, despite Greece's commitments to the opposite on account of the treaties it has signed with EU. The divide in this regard is great and it is not expected to close any time soon.

${ }^{21}$ Of questionable merit was also the support he lent in the late 1950s as advisor to the Governor of the Bank of Greece in the introduction of credit policies in favor of import substitution rather than exports.

${ }^{22}$ Perhaps it is of some importance to add that the 1975 constitution was not approved directly by the Greek people. It was ratified only by the Greek parliament.

${ }^{23}$ Note that this is the same Andreas Papandreou who wrote the above excerpts in 1962. 


\section{Conceptual Foundations of the Economies in Germany and Greece}

The fundamental principles and institutions on which the structure of the German economy presently stands had been worked out by Ordoliberal economists already before the war. So under Ludwig Erhard in 1949 one task was to embed them in the new federal constitution. Thus the constitutional lawyers who wrote it had to abstain from inserting provisions of their own which in one way or another would vitiate the precepts of an Ordoliberal economy. ${ }^{24}$ In Greece, there was no such tradition and the only restraints felt by the statist constitutional lawyers who wrote the 1952 constitution emanated from the views of Keynesian economists in the AMAG. Quite likely this is the reason that the 1952 constitution is far less statist than that which was introduced in 1975.

The objective in this section is to present the salient characteristics of the models that associate with the economic constitutions in Germany and Greece, so as to highlight their similarities and differences.

\subsection{The economic constitution in Germany: Social market economy}

The economy in Germany is structured along the lines envisaged by Ordoliberals. In particular, it is endowed with a state sector large enough and strong enough to pursue three main objectives. To safeguard that competition reigns across all sectors of the economy. To make sure that the distribution of income does not become too unequal to threaten social peace; and thirdly to set up and operate a system of public goods and of a minimal income guarantee for those who are temporarily or permanently unable to earn a living through the markets. While pursuing these objectives, the state is restrained by the obligation to respect two sets of principles, rules or institutions labelled respectively as "constitutive' and "regulative". The constitutive principles and their conceptual content have as follows:

1. The principle of competition: The state is obligated to create the institutional conditions that prevent the formation in the markets of monopolies, oligopolies and cartels that inhibit competition and undermine the maximization of social welfare.

2. The principle of private ownership of the means of production: The state must not offend through economic policy the private ownership of the means of production because all encroachments of property rights reduce the productive potential of the economic system. This does not imply that a regime of private property precludes the possibility of state ownership. If for some well-documented reasons the state gets involved in the production and distribution of goods and services, state-enterprises should be open to competition.

${ }^{24}$ According to Hasse $(2017,97)$, the climate was even more favorable because: "Due to the intense collaboration between economists and lawyers inside the Freiburg School the differing tasks could be successfully solved and institutions designed." 
3. The principle of a stable monetary system: This mandates monetary policy to be conducted so as to achieve stability in the general price level. For this result, the monetary system must operate automatically, i.e. without discretion on the part of monetary authorities. The reason being that deliberate interventions lead monetary authorities to wrong decisions, thereby maximizing the risk of inflation or deflation.

4. The principle of open markets: Introducing price and non-price barriers to markets by either the state or private parties should be prohibited. All kinds of pressure groups are interested in closing markets to realize gains by limiting competition. For this reason imposing high tariffs and import quotas to protect specific domestic producers, allowing professional and trade associations to collude and close the markets in which their members offer their services, and necessitating by the state of excessive and unwarranted formalities for doing business reduce the efficiency of domestic producers, and hence, such practices should be forbidden.

5. The principle of freedom of contract: Competition in markets develops when individuals and businesses can exchange rights they own over goods and services. Hence, private and state agents in the economy should be able to contract freely, but within the limits set by the laws. Such limits may, for example, forbid contracting to establish a cartel in a given market or to buy and sell substances dangerous to the general public.

6. The principle of accountability: In a competition based economy those who stand to gain from participating in free exchanges must bear also the losses from their actions. Expressed differently, those economic agents who make losses from their decisions should not be allowed to shift their losses to third parties. This requirement increases individual responsibility across the board and forces all participants in the economy to be extra careful with the use of the resources under their control. For example, an investment is undertaken more carefully, the more accountable the responsible person for the investment is. In other words, accountability acts as a deterrent against undertaking risky dealings with capital and enforces careful checking of markets.

7. The principle of consistency and stability of economic policies: Economic policies are intended to smooth out disturbances that develop in markets because of natural and man-made domestic and international events. For example, a flood that destroys a great deal of the agricultural production of wheat is bound to create a lot of shocks on the supply side of products based on wheat. The economic policies that will be adopted to confront the shocks should be time consistent and stable. Time consistency requires the policy makers to act as they announce over time, whereas the property of stability requires policy makers to stay the course so that economic agents may form reliable expectations.

If properly applied, the seven "constitutive" principles outlined above give rise to a free market competitive economy, which is consistent with a democratic political order and most efficient in terms of the resources used per unit output produced. But aside from these highly desirable institutional guidelines, in real life there arise certain allocative problems that need to be addressed and here is where the "regulative" principles come into force. These are the following: 
1. The problem of monopoly: For liberals in general the concentration of economic power is undesirable for two main reasons. First, because in free markets it results in elevated prices and less than socially optimal supplies of goods and services, and, second, because in politics it places the state authorities at a disadvantage, leading frequently to their capture and the introduction of arrangements that hurt the general public. To prevent undue concentrations of economic power and control the antisocial practices thereof, democracies have developed panoply of competition and antitrust laws, as well as particular institutions to enforce them. This is true also in Germany, where concentration across all markets in the economy is not allowed to exceed $40 \%$.

2. Income and social policies: In a free market economy, the price mechanism allocates the incomes to the contributing economic agents after production and exchange has been completed. The demand for goods and services by those who receive incomes determines what will be produced and in what quantities. As a result, the incomes from wages, interest and profits are inevitably determined by those who earn them, and hence the distribution of the national income is based solely on performance criteria. But then, according to Alfred Müller-Armack and others, while some classes of the population may enjoy all the luxuries in life, some other classes may be unable to secure even the mere necessities, thus creating conditions for social unrest. In view of this criticism Ordoliberals in general agreed that the state has an obligation to provide those who cannot earn a living through markets a minimum guarantee income. However, in more recent years it is widely recognized that the income and other social policies that have been adopted are excessive because they have transformed Germany into an advanced welfare state with all the drawbacks that this development entails regarding incentives for work, saving and entrepreneurial risk taking.

3. The problem of the environment: In certain cases, even when the price mechanism functions appropriately, the cost of resources is not reckoned accurately because certain production and consumption activities generate positive or negative externalities. For example, when an electric utility generates electricity by burning coal, it is possible that the electricity is under-priced because the utility does not include in its production cost the smoke and the other pollutants that it emits to the environment. In such cases economists generally agree that the state should intervene so as to force producers and consumers to include in their calculations the impact of their decisions, positive or negative, on the environment. The tension between the calculations of economic agents and the public interest can be seen also in the social area. In the past, child labour, long working hours, insufficient safety in the enterprises, etc. harmed employees and such dangers were not confronted until the state intervened and imposed codes of safety in the working environment.

4. Abnormal behaviour in the supply of labour: Eucken argued that under certain circumstances the supply of labour might be inversely related to the wage rate. By this he meant that, if workers aim at a certain income, as the wage rate declines workers would be willing to offer more labour, thus pushing the wage rate further downwards. On this ground, he recommended that a feasible policy would be for the 
state to step in and introduce a minimum wage so as to stabilize the labour market. More recent studies have shown that the dynamics of labour markets are more complicated and that raising the minimum wage may hurt workers, particularly those who lose their jobs and those who are unemployed. But this policy is now of general appeal.

To summarize, Germany's economic constitution is based on two pillars. That is, on a set of seven "constitutive" principles, which aim at establishing a competition based economy, and on another set of four "regulative" principles, which aim at confronting four types of possible market failures. According to Hasse $(2017,105)$ a trend has emerged more recently in favor of incorporating into the economic constitution several more principles. For example, under the label Principles for Governments one is the Principle to control and restrain the influence of interest groups. From these suggestions it follows that, as circumstances evolve, the model of social market economy is enriched with more institutions that seek to safeguard its fundamental tenets.

\subsection{The economic constitution in Greece: State-managed economy}

After Greece went bankrupt in 2009, international creditors offered to bail her out on the basis of an agreement signed in 2010 according to which Greece would undertake reforms in two main fronts. First, to enforce policies leading eventually to public budget surpluses, so that the huge public debt might start someday to decline as a percentage of GDP, and secondly, to reset the product and labor markets in the direction of competition and the four freedoms mandated by the single European market. ${ }^{25}$ Included in the reforms was also an extensive package of privatizations. That agreement was followed by a second one in 2012 and another in 2015 that runs until 2018.

Yet, despite the progress that has been accomplished so far regarding fiscal adjustment, primarily by raising taxes, progress in the fronts of structural reforms and privatizations is lagging seriously because conservative and leftist governments have been unwilling to take ownership. The fundamental reason is that Greek governments and the citizens who vote for them are prisoners of their own statist thinking and institutional arrangements, which have led to the formation of powerful interest groups that protect the status quo even under the present ominous national circumstances. ${ }^{26}$

${ }^{25}$ It is hardly necessary to stress that Greece not only has avoided introducing and enforcing policies in these directions but with a few exceptions since it signed the treaty for the single European market it has adopted systematically arrangements in favor of extending government controls in the economy.

${ }^{26}$ Very illuminating in this regard is the assessment by Miller and Cleverley $(2011,47)$ who write:

“... After the war, Greece packed five hundred years of Western development into five decades. Government after government attempted to break traditions of paternalistic politics and economic corruption, while offering 
How things came to this unhappy outcome is not difficult to summarize. In the two decades leading to the 1952 constitution, the organization of the Greek economy was becoming more and more statist. Administrative and other price controls prevented markets from bringing the supply and demand of goods and services into alignment, thus creating artificial surpluses and shortages. By administrative arrangements the state controlled the flow of investment in and out of the various productive sectors.

The number of public organizations and enterprises was expanding rapidly. Through direct and indirect channels the banking system served as extension and accessory of state power in the economy. Key classes of professionals like doctors, lawyers and notaries organized into professional societies aiming, among other terms, at controlling the flow of new members into their ranks and fixing the rates of their remuneration in agreement with the state, so as to maximize their rents. ${ }^{27}$

Consecutive governments, instead of letting the civil service cater to the needs of citizens, treated public sector employment as a mechanism mainly for extending patronage to their voters and secondarily to alleviate the extensive unemployment that the central management of the economy generated. With such arrangements in place and the hard core statist views that prevailed among politicians and economists, the 1952 constitution was conspicuously fuzzy regarding the nature of the economic organization envisaged by its authors. For example, while on the one hand the constitution vouched for the freedom of association (Article 11) and the protection of property rights (Article 17, paragraph 1), on the other it opened wide avenues of intervention by placing agricultural and urban cooperatives (Article 109) under the auspices of the state and by allowing forced expropriations of large agricultural farms and properties (Article 104). Perhaps because of the presence of the Americans and the pressing needs for assistance, constitutional lawmakers chose to ignore the advancing state management of the economy and left for later the articulation in the constitution of the economic order they had in mind. ${ }^{28}$

The opportunity for this arose right after the fall of the military dictatorship in 1974 and the return to power of the same people who had shaped the developments in the

Greeks the functioning political-economic infrastructure that other Western Europeans enjoyed."

27 It should be noted that these professional societies hold their own elections (in the style of parliamentary elections) and are governed by groups aligned with political parties. Furthermore, as with trade unions, by trying to achieve optimal outcomes for their members with respect to a tradeoff between wages and employment (causing some unemployment), professional societies create similar inefficiencies.

${ }^{28}$ Judging from the views they expressed in the 1930s and 1940s, the politicians and economists who came to prominence afterwards did not change their ideological convictions and persuasions. This we know from the statement of Constantinos Karamanlis in the 1970s about his adherence to socialist thinking, the editor's introduction to the 2nd edition of the book by Zolotas (1943/2009), and the details given by Angelopoulos (1992). 
1950 s and early 1960s. ${ }^{29}$ In view of the bitter experiences during the dictatorship and the need for a new start in democratic politics, the government of Constantinos Karamanlis decided to draft a new constitution, which was proposed and ratified by the Greek parliament in 1975. Not unexpectedly the economic constitution embedded in it is a prototype for a state-managed economy. It is founded on the following main principles:

1. The principle of cooperation: Given that the market mechanism is based on competition, by its very nature it promotes the animal spirits of citizens, it contributes to inequality by allowing some people to take advantage of others, and it erodes social cohesion. Thus, irrespective of its economic efficiency, the state has the obligation to replace it by institutions of cooperation and to allow competition only in those narrow productive activities in which individual initiative and energies are irreplaceable.

2. The principle of central planning: According to Article 106, paragraph 1, for the purpose of establishing "social peace" and promoting "public interest", the state plans and coordinates economic activities in the country. Through planning the state pursues: (a) the economic development of all sectors of the economy by adopting appropriate measures for the exploitation of sources of national wealth in the atmosphere, in underground and underwater deposits, and (b) the regional development, particularly of mountainous and islandic regions. Articles 79, paragraph 8, mandates that development plans are authorized by the full body of the parliament.

3. The principle of socially delimited property rights: Although by Article 17, paragraphs 1,_property owners are assured of their unalienable rights, by the provisions stated in Article 106, paragraph 2, they are forbidden to use it in ways that may insult human liberty and dignity, or cause harm to the national economy. But since the latter terms are indeterminate, property owners cannot know in advance what uses of their property might entail such offences of the law. Therefore, property rights have been seriously curtailed by imposing on them litmus tests and numerous other hurdles.

4. The principle of the state's autonomy: The state is an autonomous legal authority with rights that take precedent over those of other legal entities and individuals. As such it has prerogatives over all matters of life and death of citizens. Consequently, the state is entitled to intervene in the private affairs as it deems pertinent. In this spirit the state's actual and potential interventions are innumerable. A few indicative examples are the following:

a. With Article 16, paragraphs 5 and 8, the state retains exclusive monopoly rights over higher education. On this basis, higher education is managed as a centrally planned and administered system with all fundamental decisions taken by the Ministry of Education and applied with lim-

${ }^{29}$ This was the first "socialist phase" of Karamanlis governments. The second phase took place in the years 1974-1981. An excellent source of information regarding the way the economy was managed by the state during these decades is Halikias (1978). 
ited discretion by the universities. As for the nature of higher education this is defined as a public good, but it hardly offered as such.

b. Article 12, paragraph 6, allows the state to establish so-called "compulsory associations of individuals for the public interest." This constitutes a serious limitation of individual liberties as well as of competition because licensed professionals cannot offer their services to the public without participating in such associations and applying the recommended rates for their services. Moreover, their number is large and they are spread widely across various economic sectors.

c. Article 106, paragraph 3, provides the right of the state to nationalize or forcefully participate in any enterprise it deems appropriate for several reasons that are subsumed under the so-called "national interest". This particular right was invoked in the 1970s to nationalize several business concerns including the big Andreades Conglomerate of manufacturing, banking, shipbuilding and other companies.

5. The principle of social rights: In its autonomy and benevolence the state grants and guarantees rights over and above those subsumed under the label of "natural rights". For distinction these rights are called "social rights". The following list represents a sample from those which are explicitly referred to in the 1975 constitution:

a. All Greeks have a right to education free of charge at all levels in state schools and universities (Article 16, paragraph 4).

b. The state provides free of charge health services to all citizens and especially to those who are impotent and in old age. Also, the state looks after all citizens who lack sufficient housing (Article 21).

c. Every citizen has a right to employment and to remuneration equal to the value of the work offered (Article 22, paragraph 1).

d. The state takes care of the social insurance of workers (Article 22, paragraph 4).

e. Subject to the restrictions mentioned, all workers have a right to strike but only if they exercise it through the legally constituted labour unions (Article 23, paragraph 2). ${ }^{30}$

Associated with the "social rights" are two qualifications. Namely, first, that it is forbidden for citizens to make excessive use of them (Article 25, paragraph 3), and second, that the state has the right to demand that citizens abide by their social and national allegiance (Article 25, paragraph 4).

Moreover, the above principles are supplemented with certain state functions which address key issues like the following:

${ }^{30}$ From an economic analysis point of view there is a gross contradiction between the provision of equal pay for equal work (article 22, paragraph 1) and the right based on this provision, because labor unions negotiate for maximizing the wages not of everybody but exclusively of their own members. For this point I am indebted to Dr. Steve Bakalis. 
1. Control of radio frequency based mass media: Article 15, paragraph, 2, places the transmission of news, pictures and information through radio and television under the direct control of the state. The main objective in this arrangement is for the state to secure on behalf of the citizens the terms of operation that meet the social mission of these media.

2. Protection of the natural and cultural environment: The authorization for the state's initiatives in these areas is provided by Article 24, paragraphs $1 \& 6$. The policies that may be used for this purpose are preventive and suppressive and in the case of public forests exceptions can be allowed only if they are justified on account of the public interest.

3. City planning and restructuring: When it comes to the establishment of new cities or the rearrangement of existing ones, the state retains exceptionally wide discretionary powers to intervene, frequently at the cost of the land owners themselves. Relevant to these functions is Article 24, paragraphs 2-5.

On applying these provisions, the expectation was that there would result an economy with a large public sector and a smaller state-controlled private sector. The public sector would perform productive and distributive tasks. For example, through public enterprises and organizations, it would take the lead in the production of goods and services well beyond those that fall in the category of public goods; it would act as buffer for absorbing various shocks in the employment of workers; it would serve as a supplementary income redistribution mechanism through the pricing of public services, etc. etc. As for the private sector, this would be directed through the state-controlled banking system to activities consistent with the objectives of the central planners. Thus, in line with its top-down design, the economy that has emerged is a least competitive centrally managed state economy.

\section{Assessment}

From sections 2 and 3 it follows that right after the war a group of distinguished leaders took it upon themselves to rebuild Germany on the basis of the model of the "Social Market Economy", whereas the hearts, the minds and the choices of their counterparts in Greece were fixed on establishing a "State-managed Economy". In view of the participation of Greece in the unification process of Europe and the obligations it undertook to fulfil in the various stages, one would have expected that this great divide would have closed or at least diminished. For example, under the pressures to become from an associate member in the 1960s a full member in the early 1980s, one would have expected that all the distortions mentioned earlier in the quotations from Papandreou's (1962) book would have been confronted and that, having fulfilled its obligations under the Treaty of Rome, Greece would have become competitive enough to integrate into the community of European nations on its own strengths and merits without other considerations. Nothing of this sort happened and the 1975 economic constitution paved the way for the great divide to widen even further. The reasons for this are not hard to explain. 
As it happened in the USA, the UK and elsewhere, the rapid spread of Keynesian ideas and policies in Germany in the 1960 and 1970s forced Ordoliberalism to retreat. But from the 1980s on, due partly to the failure of Keynesian policies to deal with stagflation and partly because of the uprising in the neoliberal ideas and policies, statism in Germany was contained and started to retreat in favour of the four European freedoms that became in 1986 the basis of the Single European Market. The following quotations from two observers standing ten years apart give us a glimpse into how far this transformation has advanced and the likely direction of trends in the coming years:

“...the political conditions for a nascent resurgence of Ordoliberal policy may currently exist. Recent developments, namely the formation of Germany's second "Grand Coalition" between the SPD and CDU/CSU in 2005, broker intriguing possibilities. Recalling the first Grand Coalition's decisive role in implementing Karl Schiller's ${ }^{31}$ Keynesian economic ideas, it is conceivable that given effective leadership and a well-articulated vision (both of which are conspicuously lacking) the current party formation might marshal the political legitimacy necessary for a sweeping overhaul of the defunct Keynesian state. Wishful thinking or historical conceit, perhaps, but a provocative hypothetical nevertheless. Policymakers should think big, a new "Sprung ins kalte Wasser," and redefine an economic and social platform that is motivated by market competitiveness, price stability and limited, non-discretionary government intervention. Recent history confirms this program not as an "Anglo-Saxon invasion," but the fruition of a previously successful German academic movement." (Rittershausen, 2007, 48)

"In Germany we have a vivid discussion about the erosion of Social Market Economy by many political decisions. On the other hand in those discussions the rules and principles of Social Market Economy are again and again taken as yardsticks. And - above all - the institutional arrangements for the economy and the society are backbones of stability. Moreover, even if political decisions are obvious deviations of Social Market Economy - when the results were unfavourable they normally are changed in the direction of the principles of Social Market Economy."(Hasse, 2017, 104)

Drawing on these assessments, the preponderant likelihood is that the current status quo will not change much in the foreseeable future. The Ordoliberal principles will continue to serve as guides and reforms towards the "market" and away from the "so-

${ }^{31}$ Initially as an academic and later on as an academic-turn-politician Karl Shiller by most accounts was instrumental in the adoption of Keynesian ideas and policies by the SPD. However, Hasse et al. (2008, 65-66) have found considerable evidence to include him also among the significant contributors to Ordoliberalism. 
cial" components of the "Social Market Economy" will become more frequent and more decisive, particularly if the European experiment survives its current troubles.

Unlike Germany, in the post-war period Greece went through consecutive waves of socialism. The first one coincides with the 1955-1963 governments of Constantinos Karamanlis. Found together in the top positions of power Karamanlis-TsatsosZolotas pushed the tentacles of the state in all directions. Through credit controls practically they nationalized the banking system and enabled themselves through the so-called "annual monetary program" to direct highly subsidized investments in those sectors and activities that the technocrats of the Bank of Greece deemed as most dynamic. Through generalized price controls, including foreign exchange, they twisted the price system so as to achieve the annual monetary targets they set, and hence price stability at around $2 \%$ inflation.

Through heavy public investment they enlarged the wider public sector, thus securing the necessary institutional and industrial infrastructures, but also alleviating the rampant unemployment by overmanning public organizations and enterprises, etc. etc. If one wonders why the Greek economy did not perform less miraculously than the German economy in the period prior to the mid-1970s, ${ }^{32}$ this is the best explanation that comes to mind. All centrally managed systems perform initially well until they amass enough entropy to implode. The same happened with all socialist Eastern Europe countries and this is the reason why they have only bad memories of those experiences.

The second wave of socialism came in the period 1975- 1985 under governments initially by Karamanlis and afterwards by Papandreou, whose Pan-Hellenic Socialist Movement won the 1981 elections on a platform which included the commitment to take Greece down the road to the "Socialism of the third way." In the second half of the 1970s, the trio of Karamanlis-Tsatsos-Zolotas set to conclude their plan. No sooner had the 1975 constitution been voted in and the government of Karamanlis in quick succession nationalized a few big banks and large enterprises and introduced numerous structural reforms in the older statist tradition. As these policies were adopted by a supposedly conservative government, they were perceived by business people as "regime change" and, given that the main opposition party in the parliament promised more of the same, they started to act analogously. Total and private investment as percentages of GDP went into a long term downward trend. Foreign companies began to leave Greece and Greek companies to relocate in neighbouring countries. Unemployment climbed rapidly. The deficits in the balance of payments begun to contribute increasingly to borrowing from abroad; and in general Greece's

${ }^{32}$ During the period 1954-1974 Greece achieved: high economic growth rates $(\approx 7 \%)$, enviable price stability (<2.5\%), which enhanced the international competitiveness of Greek products and services and maintained the balance of payments under manageable control, enviable reduction of unemployment $(<2.5 \%)$, improvement and expansion of social services, and all this with very limited public debt $(<12.5 \%$ of GDP in 1974). 
annual average rate of growth trended significantly lower than in the pre-1974 period. ${ }^{33}$ If on top of the above we reckon that after 1974, and especially after 1981, Greek governments undermined with their policies the ability of the country to survive within the competitive EU environment, Greece's decline was all but certain.

The laxity with which EU leaders and institutions treated Greece with regard to the fulfilment of her obligations created "Moral Hazard" issues throughout Europe and as such it has been severely criticized. For example, Bitros $(2015,7)$ writes:

When the European Commission "froze" the Association Agreement in 1967 reacting to the imposition of military rule in Greece, the message was clear and loud: It stressed the commitment of the EU to democracy, and, by doing so, it created a precedent for all European nations with aspirations similar to those of Greece. Yet, after the restoration of Democracy in 1974 and the re-activation of the Association Agreement, the European authorities failed to notice that the institutional changes in Greece were inconsistent with the main pillars of the Treaty of Rome. Let me explain: Bitros and Karayiannis (2013) establish that Democracy is impossible to take root and flourish without a free market economy. Quite expectedly this finding explains why the founding fathers of the EU constructed the Treaty of Rome on the twin pillars of democracy and the free market economy. However, the institutional changes in Greece, particularly after 1974, worsened its structural imbalances even further than in 1961.

Unfortunately, EU authorities continued to look the other way ever since. For example they raised no eyebrows when in the early 1980s Papandreou's government set up a state subsidized scheme to save long defunct industrial enterprises. They did not raise hell when government after government procrastinated and adopted policies moving the Greek economy away from the four European freedoms; and even now in a period of extreme hardship for the Greek people they pay leap service to the European Project by allowing Greek governments to maintain almost intact the central administration of the economy.

There is some light though at the end of the tunnel. This emanates from the unrelenting demolition by the International Monetary Fund (IMF) of the 1975 economic constitution. Under the threat of an open bankruptcy, gone are the national and sectoral labour agreements. In are the enterprise labour contracts. Gone are the various impediments to employee lay-offs. In are all sorts of flexible labour market arrangements. Perhaps, if

${ }^{33}$ After 1974, the average annual growth rate fell to about one third $(\approx 2.4 \%)$, the unemployment rate, which more than doubled in the period 1980-2000 ( $\approx 6 \%)$, in the decade of 2000 nearly quadrupled $(\approx 9 \%)$, the explosive deficits in the balance of payment were contained only thanks to the huge EU aid, and the budget deficits pushed public debt to an unsustainable ratio $(\approx 150 \%$ of the GDP in 2011). 
and when all structural reforms which have been recommended by the Organization for Economic Cooperation and Development (OECD) are implemented the great divide with Germany will start to close and robust and sustainable economic growth will return for good in Greece, together with the four freedoms of the single European market.

\section{Implications for the future of the $\mathrm{EU}$}

One great ambition of the founding fathers of the EU was that someday memberstates would enjoy roughly comparable living standards (Allegret et al., 2016; Boldeanu and Tache, 2016). As all were expected to grow at about the same speed, no member-state would be left behind and those who entered with a handicap would be assisted to catch up. This benevolent idea became in turn the basis for the establishment of the so-called European structural funds, which were assigned the task to assist laggard member-states to streamline their economies so as to raise their growth rates. Unfortunately, the assistance from the structural funds and the other EU facilities proved ineffective in this regard and more recently the EU political leaders were forced to start thinking about an EU in which member-states would grow at their own speeds.

This development is important because it reveals the hard way that top-down approaches to smoothing differences among nations do not work when differences are path dependent and spring mostly from their systems of values, educational backgrounds, preferences, ideological inclinations, and even climate dispositions. Over the period 1981-2010 it is estimated that Greece received from EU net financial assistant amounting on the average to about $2.7 \%$ of GDP per annum. This was an exceedingly generous assistance and proves the true allegiance of European nations to a less developed member-state. But Greece abrogated its main treaty obligations, it resisted systematically all pressures for restructuring so as to converge to the European economies and in fact it chose and applied an economic constitution totally inconsistent with the principles of a normal market economy. As a result, in those indices that matter most it has diverged rather than converged and this would have happened irrespective of the amount of assistance.

What can we learn from the case of Greece which would be useful for the future of EU? One lesson is that the emphasis of convergence must switch from indices of economic performance to indices of achievements in the four European freedoms For, if member-states are in the EU for the ideas and the life-styles it represents, then the differences that count are not in the living standards, but in the degrees to which the four freedoms take hold across the Euroland; and, also, because faster progress in the four freedoms, aside from precipitating the convergence in per-capita incomes and other indices of material well-being, will smooth out differences in politics by reducing the democratic deficit in the EU.

Another lesson is that member-states should be held more closely accountable for conforming to the terms of the European treaties. This implies that existing Europe- 
an institutions have proved ineffective and that there is now need for reforms in two directions: First, to improve monitoring and enforcement, particularly in the implementation of the four freedoms; and, second, to do so not by expanding the central bureaucracy in Brussels but by intelligent mechanisms design and implementation. A last lesson, but not least, is that the structural funds may be expected to become more effective in the realization of the European unification if they switch from subsidizing projects for economic convergence to projects aspiring to enhancing one or more of the four freedoms.

In short, if there is a single lesson to be learnt from Greece that would be useful for the future of Europe, this is that European unification depends far more in the widening and deepening of the four European freedoms than in any measure of convergence in living standards (Thalassinos et al., 2015). This is not to say that the latter criterion is not important. But certainly it is of secondary order.

\section{Summary of findings and conclusions}

In the last four decades Greece received from the EU not less than 180 billion Euros of net financial assistance. On a per capita basis this amounts to an unprecedented inflow of aid by world standards. Moreover, these funds were used under the monitoring and watchful eyes of the European agencies and institutions. Yet in 2009 Greece went bankrupt and had to be bailed out by its international and European creditors with terrible hardships for the Greek people. Something has gone terribly wrong which has led me to search for the reasons and in view of the findings to suggest possible actions and policies for getting out of this quagmire.

In this paper I focused my attention on a detailed comparison of the roots and the evolution of the economic constitutions that applied in Germany and Greece in the post-war period. Given that from its inception the EU has been founded on treaties that incorporate ideas and policy directions from the German economic order, my hunch was that, if the economic constitution in Greece has diverged from that in Germany, the structure of the Greek economy would have diverged all this time from EU fundamentals and this might have contributed significantly to its bankruptcy. The findings that have emerged from this comparison are straightforward. Whereas the four European freedoms are in line with the German essentially Ordoliberal economic order, the economic constitution in Greece has promoted a state-managed economy. This is the great divide which certainly has contributed to the bankruptcy of Greece and explains thoroughly why she refuses to take ownership of the necessary reforms so as to return quickly to a path of robust economic growth.

The implications of these findings for the EU are also straightforward. In particular, emphasis from economic convergence should be replaced by emphasis on the four European freedoms; monitoring and enforcement of EU treaties should be reinforced by relying more on automatic mechanisms and less on bureaucratic man-driven processes, and the nature of projects financed by the structural funds should be com- 
pletely overhauled in the direction of subsidizing projects that enhance the realization of the fundamental EU freedoms.

\section{References:}

Allegret, J.P., Raymond, H. and Rharrabti, H. 2016. The Impact of the Eurozone Crisis on European Banks Stocks, Contagion or Interdependence. European Research Studies Journal, 19, 129-147.

Angelopoulos, A. 1992. Economics, Vol. 3, Athens: Papazisis Press (in Greek).

Barry, N. 2013. Germany: From the market to socialism-and back? Foundation for Economic Education, https://fee.org/articles/germany-from-the-market-to-socialism-and-back/

Baum, H.J. 1990. The German economy in the twentieth century, London: Routledge.

Bitros, G.C. 2013. From riches to rags or what went wrong in Greece, in G.C. Bitros (Guest editor) "On Greece and Greek Statistics." Journal of Economic and Social Measurement, 38, 5-39.

Bitros, G.C. 2015. European Union failures in Greece and some possible explanations, in G.C. Bitros, and Kyriazis, N.C. (Eds.), Essays in contemporary Economics: A Festschrift in Memory of A.D. Karayiannis, New York: Springer International Publishing.

Bitros G.C. and Karayiannis A.D. 2013. Creative crisis in democracy and economy, Berlin: Springer.

Bitros G.C., and Karayiannis, A.D. 2011. The socialist roots of x-liberalism in Greece. Science and Society, 28, 168-206, (in Greek).

Boldeanu, T.F., Tache, I. 2016. The Financial System of the EU and the Capital Markets Union. European Research Studies Journal, 19, 60-70.

Habermas, J, 2018. Are we Still Good Europeans? Acceptence speech on receiving the French-German_Media Prize, retrievable from https://www.socialeurope.eu/arewe-still-good-eyropeans/

Halikias, D.J. 1978. Money and Credit in a Developing Economy: The Greek Case. New York University Press.

Hasse, R. 2017. The German Concept of Market Economy: Social Market Economy. Its Roots and Its Contribution to Liberal Economic Orders in Germany, Europe and Beyond. In Bitros G.C., and Kyriazis, N.C. (Eds.) Democracy and an OpenEconomy World Order, Cham, SW: Springer, 93-108.

Hasse, R., Sneider, H., and Weigelt, K. (Eds.) 2008. Social market economy principles and implementation: Economic policy from A to Z. Johannesburg: Konrad-AdenauerStiftung.

Hatzivassiliou, E. 2010. Greek Reformism and its Models: The Impact of the Truman Doctrine and the Marshall Plan. Journal of Modern Greek Studies, 28, 1-25.

Giersch, H., Paque, K.H., and Schmieding, H. 1994. The Fading Miracle: Four Decades of Market Economy in Germany, Cambridge: Cambridge University Press.

Miller, J., and Cleverley, M. 2011. Greece's Struggle to Escape the Past: A View from Inside. Mediterranean Quarterly, 22, 46-61.

Moravscik, A. 2001. Despotism in Brussels? Misreading the European Union. Foreign Affairs, 80(3), 114-122.

Papandreou, A.G. 1962. A Strategy for Greek Economic Development. Athens, Center of Economic Research, Research Monograph 1.

Paul, E.F., Miller, F.D. and Paul, J. (Eds.) 1993. Liberalism and the economic order. New York, Cambridge University Press. 
40

Rittershausen, J.R.B. 2007. The postwar West German economic transition: From Ordoliberalism to Keynesianism. Institut für Wirtschaftspolitik an der Universität zu Köln Discussion Paper No. 2007/1.

Siedentop, L. 2001. Despotism in Brussels? Misreading the European Union, New York, Columbia University Press.

Smith, M.P. 2001. Europe and the German Model: Growing Tension or Symbiosis German Politics, 10, 119-140.

Thalassinos, I.E., and Stamatopoulos, Th. 2015. The Trilemma and the Eurozone: A PreAnnounced Tragedy of the Hellenic Debt Crisis. International Journal of Economics and Business Administration, 3(3), 27-40.

Thalassinos, I.E., Pintea, M., and Raţiu, I.P. 2015. The Recent Financial Crisis and Its Impact on the Performance Indicators of Selected Countries during the Crisis Period: A Reply. International Journal of Economics and Business Administration, 3, 3-20.

Tomai, F. (Ed.) 2011. Documentary History of Greece (1943-1951): Truman Doctrine and Marshall Plan. Athens Papazisis Press.

Van Hook, J.C. 2004. Rebuilding Germany: The Creation of the Social Market Economy, 1945-1957. New York, Cambridge University Press.

Vanberg, V.J. 2004. The Freiburg School: Walter Eucken and Ordoliberalism. Walter Eucken Institut, Freiburg Discussion Papers on Constitutional Economics, No. 4/11, Freiburg.

Zolotas, X. 2009. Creative Socialism, $2^{\text {nd }}$ edition, Athens, Sakkoulas Press (in Greek). 


\section{Appendix:}

Table 1: Select sample of economic indicators for Greece and Germany

\begin{tabular}{|l|l|l|}
\hline Year 2015 & \multicolumn{1}{|c|}{ Greece } & Germany \\
\hline GDP per capita (EUR) & 17117 & 33869 \\
\hline GDP growth (\%) & -0.23 & 1.45 \\
\hline GDP gap ${ }^{1}$ & -6.57 & -0.11 \\
\hline Investment (\% of GDP) & 9.83 & 18.83 \\
\hline Inflation (\% of annual change) & -1.09 & 0.14 \\
\hline Unemployment (\% of the labor force) & 25 & 4.63 \\
\hline Imports of goods and services (\% change) & -5.77 & 5.83 \\
\hline Exports of goods and services (\% change) & -7.94 & 5.39 \\
\hline General government revenues (\% of GDP) & 45.77 & 44.61 \\
\hline General government outlays (\% of GDP) & 49.99 & 43.97 \\
\hline Government debt to GDP (\%) & 177.0 & 71.2 \\
\hline Private debt to GDP (\%) & 140.0 & 150.0 \\
\hline Wage per month (EUR) & 1116 & 3624 \\
\hline Personal income tax rate (\%) & 48.0 & 47.5 \\
\hline Corporate tax rate (\%) & 29.0 & 29.65 \\
\hline $\begin{array}{l}\text { Notes: } \\
\text { 1. The GDP gap measures the unused productive capacity of the economy. In Greece it is } \\
\quad \text { so high because of the prevailing recession. }\end{array}$ & \\
$\begin{array}{l}\text { Sources: } \\
\text { http://www.economywatch.com/economic-statistics/country/ }\end{array}$ \\
\begin{tabular}{l} 
http://www.tradingeconomics.com/country/indicators \\
\hline
\end{tabular} \\
\hline
\end{tabular}


Table 2: Quality of institutions and governance in the year 2015

\begin{tabular}{|c|c|c|c|c|}
\hline Governance Score & $\begin{array}{l}\text { Government } \\
\text { Effectiveness }{ }^{1}\end{array}$ & $\begin{array}{l}\text { Regulatory } \\
\text { Quality }^{2}\end{array}$ & $\begin{array}{l}\text { Rule of } \\
\text { Law }^{3}\end{array}$ & $\begin{array}{l}\text { Control of } \\
\text { Corruption }^{4}\end{array}$ \\
\hline Germany & 1.74 & 1.67 & 1.78 & 1.82 \\
\hline Greece & 0.25 & 0.40 & 0.24 & -0.13 \\
\hline \multicolumn{5}{|c|}{$\begin{array}{l}\text { Notes: } \\
\text { 1. Government Effectiveness (GE) reflects perceptions of the quality of public services; } \\
\text { the quality of the civil service and the degree of its independence from political pres- } \\
\text { sures; the quality of policy formulation and implementation; and the credibility of the } \\
\text { government's commitment to such policies. } \\
\text { 2. Regulatory Quality: Regulatory quality captures perceptions of the ability of the gov- } \\
\text { ernment to formulate and implement sound policies and regulations that permit and } \\
\text { promote private sector development. This table lists the individual variables from each } \\
\text { data sources used to construct this measure in the Worldwide Governance Indicators } \\
\text { 3. Rule of Law: reflects perceptions of the extent to which agents have confidence in and } \\
\text { abide by the rules of society, in particular the quality of contract enforcement, property } \\
\text { rights, the police, and the courts, as well as the likelihood of crime and violence. } \\
\text { 4. Control of Corruption: reflects perceptions of the extent to which public power is exer- } \\
\text { cised for private gain, including both petty and grand forms of corruption, as well as } \\
\text { "capture" of the state by elites and private interests. }\end{array}$} \\
\hline $\begin{array}{l}\text { Source: } \\
\text { http://info.worldba }\end{array}$ & & & & \\
\hline
\end{tabular}

